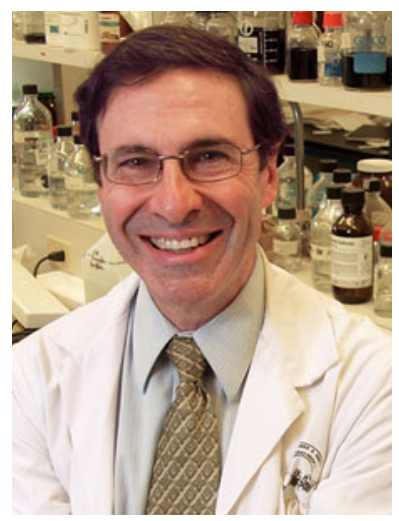

\section{A tribute to Mark Wainberg, a pioneer in HIV/AIDS research}

It was with great sadness that the Canadian scientific community learned, on April 11, 2017, of the death of Mark Wainberg. Mark was Director of the McGill AIDS Centre and Professor of Microbiology and Immunology at McGill University. He was also Head of the Laboratory for Research on AIDS at the Lady Davis Institute for Medical Research, Jewish General Hospital, Montreal, Quebec. In recognition of the importance of his work in the advancement of public health, in particular with regard to HIV/AIDS research and advocacy, the Journal opened its editorial page to one of his close collaborators in order to share this tribute to a giant in Canadian public health.

\section{FAREWELL MARK}

Tributes poured in from scientists, clinicians, public health leaders, and community advocates around the world when news broke that Canadian molecular biologist Mark Wainberg had drowned off the Florida coast at Bal Harbour on April 11, 2017. He had been on holiday over Passover with his family when he got into difficulty in rough water. Zev Wainberg, his oncologist son from Los Angeles, tried unsuccessfully to revive him. Initial shock, disbelief and sadness provoked by this senseless tragedy gave way to a deepening appreciation of Mark Wainberg's legacy.

Just in March, Mark had organized and chaired the successful Journées québécoises sur le VIH in Montreal. A few weeks later, on April $6^{\text {th }}$, he introduced - as he did each year - the Mark Wainberg Lecture at the Canadian Association for HIV Research conference. Given annually since 2003 by a lead Canadian human immunodeficiency virus (HIV) researcher, the lecture was in recognition of Mark's ongoing contributions to the HIV field and he had always joked about it being 'pre-memorial'. Five days later he was gone, having left a big footprint.

While those who had known him personally were dumbfounded and saddened, countless people around the world did not know that he had played a role in profoundly changing the course of their lives. As McGill's Dean of Medicine David Eidelman stated: "Mark Wainberg had an inestimable impact on the lives of millions of people through his transformative research and extraordinary advocacy." ${ }^{1}$ The Executive Director of UNAIDS in Geneva, Michel Sidibé, described him as a "giant of HIV science. His work contributed to saving millions of lives." ${ }^{2}$

\section{Hommage à Mark Wainberg, pionnier de la recherche sur le $\mathrm{VIH}$ et le sida}

C'est avec une grande tristesse que la communauté scientifique canadienne a appris, le 11 avril 2017, le décès de Mark Wainberg. Mark était directeur du Centre sur le sida de l'Université McGill et professeur de microbiologie et d'immunologie à l'Université McGill. Il était aussi le chef du laboratoire de recherche sur le sida de l'Institut Lady Davis pour la recherche médicale à l'Hôpital général juif de Montréal (Québec). Étant donné l'importance de son travail de promotion de la santé publique, en particulier en ce qui a trait à la recherche et à l'action sociale sur le VIH et le sida, la Revue ouvre sa page éditoriale à une proche collaboratrice de Mark Wainberg afin de partager cet hommage à un géant de la santé publique canadienne.

\section{ADIEU, MARK}

Les hommages de scientifiques, de cliniciens, de responsables de la santé publique et d'intervenants du milieu associatif du monde entier ont afflué lorsqu'on a publié la nouvelle de la noyade du biologiste moléculaire canadien Mark Wainberg au large de la Floride à Bal Harbour le 11 avril 2017. Il passait les vacances de la Pâque juive avec sa famille lorsqu'il s'est trouvé en difficulté en eau agitée. Son fils Zev Wainberg, oncologue à Los Angeles, a essayé sans succès de le ranimer. Le choc initial, l'incrédulité et la tristesse provoqués par cette tragédie insensée ont laissé place à une appréciation grandissante pour l'héritage de Mark Wainberg.

Encore en mars dernier, Mark avait organisé et présidé les fructueuses Journées québécoises sur le VIH à Montréal. Quelques semaines plus tard, le 6 avril, il avait présenté - comme il le faisait chaque année - la personne ayant reçu l'honneur de prononcer la conférence Mark-Wainberg de l'Association canadienne de recherche sur le VIH. Donnée chaque année depuis 2003 par un chercheur canadien de premier plan travaillant sur le virus de l'immunodéficience humaine (VIH), cette conférence était un hommage aux efforts incessants de Mark dans le domaine du VIH; celui-ci avait d'ailleurs toujours dit, en plaisantant, que c'était une conférence " pré-commémorative ». Cinq jours plus tard, il disparaissait, laissant une grosse pointure à remplir.

Les gens qui l'ont connu personnellement ont bien sûr été sidérés et attristés, mais d'innombrables personnes autour du monde ignoraient qu'il avait contribué aussi profondément à changer le cours de leur vie. Comme l'a déclaré le doyen de la Faculté de médecine de l'Université McGill, David Eidelman : « Mark Wainberg a joué un rôle inestimable dans la vie de millions de personnes grâce à ses recherches porteuses de changement et à son 
Who was Mark Wainberg? At Mark's funeral in Montreal, Zev Wainberg described him as a complicated, humble, brilliant man. Despite this apt description, Mark really fit no mould. He was a basic scientist who had moved well beyond the laboratory to influence policy and programs ${ }^{3}$ - but he had begun and continued in the lab. After spending a sabbatical period as a visiting scientist in Robert Gallo's laboratory at the National Institutes of Health in 1980-81, Mark established the first HIV laboratory in Canada. In the mid-80s, he was named to the National Advisory Committee on AIDS, and in 1989 his team was involved in the identification of 3TC, also known as lamivudine. This antiretroviral drug continues to this day to be part of the therapeutic armamentarium of multidrug HIV cocktails that have changed HIV infection from a certain death sentence to a chronic disease. Mark went on to be among the first to identify the problem of HIV drug resistance and to speak out about its importance.

His scientific credentials were unassailable. By the time he died, Mark had authored or co-authored an astounding 580 peerreviewed publications and 309 book chapters, reviews, editorials and commentaries. The credibility he had earned through his science opened doors for him to speak out and be heard. When the South African government of Thabo Mbeki refused to make the antiretroviral drug nevirapine available to pregnant women living with HIV to prevent mother-to-child transmission, the Treatment Action Campaign (TAC) took the government to court. The government then filed a 1000-page affidavit that claimed that nevirapine resistance would lead to a public health catastrophe in South Africa. Urgently needing a world expert in virology and immunology, TAC sought out Mark Wainberg. Within five days, he wrote a detailed affidavit arguing that nevirapine use should be encouraged and that its effectiveness should take precedence over considerations of drug resistance. He took it to the South African embassy in Ottawa to get it sworn and certified so that TAC could include it in its court papers. When the government was ordered by the High Court in December 2001 to roll out nevirapine, it went to the Constitutional Court, which upheld the High Court order in 2002. ${ }^{4}$ Finally, HIV transmission to offspring during pregnancy, delivery and breastfeeding could be prevented in South Africa.

Mark had been marked as an enemy of the South African government well before this. While President of the International AIDS Society from 1998 to 2000, he was instrumental in bringing the International AIDS Conference to Durban in 2000. Chaired by Salim Abdool Karim and Jerry Coovadia, this was the first to be held outside Europe or North America. Opened by Thabo Mbeki, who denied that HIV caused AIDS, and closed by Nelson Mandela, who stated that he knew that Mbeki would take the right decision, it showcased the lack of access to life-saving antiretroviral treatment for millions of Africans. Thousands of researchers signed The Durban Declaration, arguing that the evidence that AIDS is caused by HIV is clear-cut, exhaustive and unambiguous, meeting the highest standards of science. ${ }^{5}$

Mbeki did not budge until 2006, at which time he reversed his position, telling his deputy Phumzile Mlambo-Ngcuka to open negotiations with TAC, a month after political pressure had been generated by the 2006 International AIDS Conference in Toronto that Mark co-chaired. Delegates had been horrified when, under the leadership of the notorious Manto Tshabalala-Msimang, dubbed the Minister of Death, the South African exhibit featured

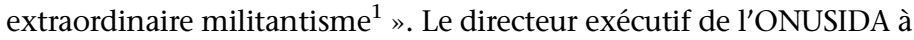
Genève, Michel Sidibé, l'a qualifié de " géant dans la science du sida. Son travail a sauvé des millions de vies ${ }^{2}$.»

Qui était Mark Wainberg? Pendant les funérailles à Montréal, Zev Wainberg l'a décrit comme étant un homme compliqué, humble, brillant. C'est une bonne description, mais Mark n'entrait vraiment dans aucun moule. Spécialiste des sciences fondamentales, il exerçait une influence bien au-delà des murs du laboratoire, sur les politiques et les programmes ${ }^{3}$ - mais c'est au laboratoire qu'il avait commencé et qu'il poursuivait ses efforts. Après un congé sabbatique comme chercheur invité au laboratoire de Robert Gallo aux National Institutes of Health en 1980-1981, Mark avait établi le premier laboratoire de recherche sur le VIH au Canada. Au milieu des années 1980, il a été nommé au Comité consultatif national sur le sida, et en 1989, son équipe a contribué à identifier le 3TC, qu'on appelle également la lamivudine. Encore aujourd'hui, cet antirétroviral fait partie de l'arsenal thérapeutique du cocktail de médicaments contre le VIH qui ont transformé l'infection à VIH d'une sentence de mort certaine à une maladie chronique. Mark a ensuite été parmi les premiers à cerner le problème de la résistance aux médicaments antiVIH et à en souligner l'importance.

Sa crédibilité scientifique était imprenable. Au moment de sa mort, Mark avait écrit, seul ou en collaboration, le nombre prodigieux de 580 articles évalués par des pairs et 309 chapitres de livres, critiques, éditoriaux et commentaires. La crédibilité qu'il avait acquise par son savoir scientifique lui a ouvert la possibilité de s'exprimer et d'être entendu. Quand le gouvernement d'Afrique du Sud de Thabo Mbeki avait refusé de mettre la névirapine, un antirétroviral, à la disposition des femmes enceintes vivant avec le VIH pour prévenir la transmission mère-enfant, la Campagne d'action en faveur des traitements, ou TAC, avait traduit le gouvernement en justice. Le gouvernement avait répliqué en déposant un affidavit de 1000 pages alléguant que la résistance à la névirapine entraînerait un problème de santé publique catastrophique en Afrique du Sud. Ayant impérativement besoin d'un spécialiste mondial en virologie et en immunologie, la TAC a fait appel à Mark Wainberg. En cinq jours, celui-ci a rédigé un affidavit détaillé faisant valoir que l'utilisation de la névirapine devait être encouragée, et que son efficacité devait avoir préséance sur toute considération de pharmacorésistance. Il a déposé cet affidavit à l'ambassade d'Afrique du Sud à Ottawa pour le faire assermenter et certifier, afin que la TAC puisse l'inclure dans ses documents judiciaires. En recevant l'ordre de la Haute Cour, en décembre 2001, de déployer la névirapine, le gouvernement s'est adressé à la Cour constitutionnelle, laquelle a maintenu l'ordonnance de la Haute Cour en $2002^{4}$. Il est alors enfin devenu possible de prévenir la transmission du VIH aux bébés durant la grossesse, l'accouchement et l'allaitement en Afrique du Sud.

Bien avant ces événements, Mark était déjà considéré comme un ennemi du gouvernement sud-africain. Durant sa présidence de la Société internationale du sida de 1998 à 2000, il avait contribué à faire venir la Conférence internationale sur le sida à Durban en 2000. Présidée par Salim Abdool Karim et Jerry Coovadia, ce fut la première conférence à se tenir hors d'Europe ou d'Amérique du Nord. Inaugurée par Thabo Mbeki, qui niait que le VIH soit la cause du sida, et clôturée par Nelson Mandela, qui avait exprimé la conviction que Mbeki prendrait la bonne décision, cette conférence avait mis en lumière le manque d'accès de millions d'Africains aux traitements antirétroviraux susceptibles de sauver des vies. Des milliers de chercheurs ont signé la Déclaration de Durban, qui fait valoir que les preuves que le sida est causé par le VIH sont claires, exhaustives et sans équivoque, et qu'elles répondent aux normes scientifiques les plus strictes ${ }^{5}$. 
only garlic, lemons and African potatoes to treat AIDS. Mark and his colleague John Moore subsequently wrote that the number of people living with HIV in South Africa was 25\% higher than would otherwise have been the case because of that country's denialist policies. "Mbeki and his health minister had been among those in Africa whose insistence on propagating flagrant disinformation about the disease, amounted to an arguably criminal abrogation of leadership." 6

Among the many awards that Mark received were France's Chevalier de la Légion d'Honneur in 2008, an Honorary Doctorate in Medicine from the Faculté de Médicine, Université de Montréal in 2011, and the Killam Prize for Health Sciences in 2012. He was an Officer of the Order of Canada, Canada's highest civilian award. In 2016, he was inducted into the Canadian Medical Hall of Fame for having revolutionized our understanding of HIV "at the medical, epidemiological, and political levels." ${ }^{7}$

Mark had formally supervised close to 50 early-career researchers in his laboratory and was a mentor to many more. Always approachable, he made nurturing the next generation of scientists a priority. Many tributes have come in from those he encouraged, now mid-career and senior investigators.

He loved to speak, at the drop of a hat, in English or French. He made around 600 presentations at seminars and conferences, in addition to those at McGill University where he was Professor and Director of the McGill AIDS Centre, Professor of Microbiology and Immunology, Professor in the Departments of both Medicine and Paediatrics, and Head of the Laboratory for Research on AIDS at the Lady Davis Institute for Medical Research, Jewish General Hospital, Montreal.

Mark always had an opinion, mostly right and rarely wrong and he was always ready to change his mind if the evidence warranted it. He had a wonderful sense of humour, with an impish grin at the ready for a good laugh. We miss him! Linda-Gail Bekker, President of the International AIDS Society, summed him up well: "Mark was a true mensch and a great scientist and an even better friend." 8

\section{Catherine Hankins,}

Deputy Director, Amsterdam Institute for Global Health and Development; Professor of Population and Public Health, Faculty of Medicine, McGill University, Montreal, QC

doi: $10.17269 /$ CJPH.108.6283

\section{REFERENCES}

1. AIDS pioneer Mark Wainberg dies in Florida. McGill Reporter [Internet]. 2017 Apr 12. Available at: http://publications.mcgill.ca/reporter/2017/04/ aids-pioneer-mark-wainberg-dies-in-florida/ (Accessed May 23, 2017).

2. European AIDS Treatment Group. UNAIDS saddened by the death of HIV researcher Mark Wainberg [Internet]. 2017. Available at: http://www.eatg.org/ news/unaids-saddened-by-the-death-of-hiv-researcher-mark-wainberg/ (Accessed May 23, 2017).

3. Sandomir R. Dr. Mark Wainberg, who identified a key AIDS drug, dies at 71 . The New York Times [Internet]. 2017 Apr 14. Available at: https://www. nytimes.com/2017/04/14/world/americas/dr-mark-wainberg-microbiologistaids-awareness-dead.html (Accessed May 23, 2017).

4. HIV/Aids researcher who forced Mbeki U-turn drowns in Florida. Medical Brief: Africa's Medical Media Digest [Internet]. 2017 Apr 26. Available at: http://www.medicalbrief.co.za/archives/hivaids-researcher-forced-mbeki-uturn-drowns-florida/ (Accessed May 23, 2017).

5. The Durban Declaration. Nature 2000;406(6791):15-16. PMID: 10894520. doi: $10.1038 / 35017662$.
Mbeki n'a pas bronché avant 2006, après quoi il est revenu sur sa position et a demandé à sa députée, Phumzile Mlambo-Ngcuka, d'ouvrir les négociations avec la TAC, un mois après les pressions politiques générées par la Conférence internationale sur le sida tenue en 2006 à Toronto et coprésidée par Mark. Les délégués avaient été horrifiés lorsque, sous la direction de la tristement célèbre Manto Tshabalala-Msimang, appelée " ministre de la Mort », le stand sud-africain n'avait proposé que de l'ail, des citrons et des pommes de terre africaines comme traitements contre le sida. Mark et son collègue John Moore avaient écrit par la suite que le nombre de personnes vivant avec le VIH en Afrique du Sud était supérieur de $25 \%$ à ce qu'il aurait pu être à cause des politiques de déni de ce pays. "Mbeki et sa ministre de la Santé comptent parmi ceux qui, en Afrique, insistent pour propager de la désinformation flagrante au sujet de cette maladie, ce qui revient à une abdication de leadership possiblement criminelle ${ }^{6}$. »

Entre autres prix honorifiques, Mark a été fait chevalier de la Légion d'honneur par la France en 2008, il a reçu un doctorat de médecine honoris causa de la Faculté de médicine de l'Université de Montréal en 2011, ainsi que le prix Killam en sciences de la santé en 2012. Il était Officier de l'Ordre du Canada, la plus haute décoration civile du pays. En 2016, il a été intronisé au Temple de la renommée médicale canadienne pour avoir révolutionné notre compréhension du VIH « aux niveaux médical, épidémiologique et politique $^{7}$ ».

Mark a officiellement supervisé près de 50 jeunes chercheurs dans son laboratoire et en a mentoré bien davantage. Toujours très accessible, il considérait que l'éducation de la nouvelle génération de scientifiques était une priorité. De nombreux hommages sont venus de ceux et celles qu'il a encouragés et qui sont maintenant des chercheurs à mi-carrière ou chevronnés.

Il aimait parler, à l'improviste, en anglais ou en français. Il a donné environ 600 présentations lors de séminaires et de congrès, en plus de ses conférences à l'Université McGill, où il était professeur et directeur du Centre sur le sida, professeur de microbiologie et d'immunologie, professeur aux départements de médecine et de pédiatrie, et chef du laboratoire de recherche sur le sida à l'Institut Lady Davis pour la recherche médicale de l'Hôpital général juif de Montréal.

Mark avait toujours une opinion, juste la plupart du temps, rarement fausse - et il était disposé à changer d'idée si les preuves le justifiaient. Il avait un merveilleux sens de l'humour, avec un sourire malicieux, prêt à rire de bon cœur. Comme il nous manque! Le portrait qu'en a fait Linda-Gail Bekker, présidente de la Société internationale du sida, le résume bien : «Mark était un homme bon, un grand scientifique et un ami encore plus grand ${ }^{8}$.»

Catherine Hankins,

Directrice adjointe de l'Institut d'Amsterdam pour la santé mondiale et le développement; professeure de santé publique et santé de la population à la Faculté de médecine de l'Université McGill, Montréal (Québec)

doi: $10.17269 / \mathrm{C} \mid \mathrm{PH} .108 .6283$

\section{RÉFÉRENCES BIBLIOGRAPHIQUES}

1. AIDS pioneer Mark Wainberg dies in Florida. McGill Reporter [Internet]. 2017 Apr 12. Sur Internet : http://publications.mcgill.ca/reporter/2017/04/ aids-pioneer-mark-wainberg-dies-in-florida/ (consulté le 23 mai 2017).

2. European AIDS Treatment Group. UNAIDS saddened by the death of HIV researcher Mark Wainberg [Internet]. 2017. Sur Internet : http://www.eatg.org/ news/unaids-saddened-by-the-death-of-hiv-researcher-mark-wainberg/ (consulté le 23 mai 2017). 
6. Wainberg M, Moore J. AIDS and the dangers of denial. Globe and Mail [Internet]. 2007 Jul 4. Available at: https://www.theglobeandmail.com/news/ national/aids-and-the-dangers-of-denial/article1077907/ (Accessed May 23, 2017).

7. Mark Wainberg [Internet]. Canadian Medical Hall of Fame. 2016. Available at: http://cdnmedhall.org/inductees/markwainberg (Accessed May 23, 2017).

8. Picard A. OBITUARY Mark Wainberg, dead at 71, was 'a giant of HIV science'. The Globe and Mail [Internet]. 2017 Apr 21. Available at: http://v1. theglobeandmail.com/servlet/story/LAC.20170422.OBMARKWAINBERG/ BDAStory/BDA/deaths (Accessed May 23, 2017)
3. Sandomir R. Dr. Mark Wainberg, who identified a key AIDS drug, dies at 71 The New York Times [Internet]. 2017 Apr 14. Sur Internet : https://www. nytimes.com/2017/04/14/world/americas/dr-mark-wainberg-microbiologistaids-awareness-dead.html (consulté le 23 mai 2017).

4. HIV/Aids researcher who forced Mbeki U-turn drowns in Florida. Medical Brief: Africa's Medical Media Digest [Internet]. 2017 Apr 26. Sur Internet : http:// www.medicalbrief.co.za/archives/hivaids-researcher-forced-mbeki-u-turndrowns-florida/ (consulté le 23 mai 2017).

5. The Durban Declaration. Nature 2000;406(6791):15-16

6. Wainberg M, Moore J. AIDS and the dangers of denial. Globe and Mail [Internet]. $2007 \mathrm{Jul} 4$. Sur Internet : https://www.theglobeandmail.com/news/ national/aids-and-the-dangers-of-denial/article1077907/ (consulté le 23 mai 2017).

7. Mark Wainberg [Internet]. Canadian Medical Hall of Fame. 2016. Sur Internet : http://cdnmedhall.org/inductees/markwainberg (consulté le 23 mai 2017).

8. Picard A. OBITUARY Mark Wainberg, dead at 71, was 'a giant of HIV science'. The Globe and Mail [Internet]. 2017 Apr 21. Sur Internet : http://v1 theglobeandmail.com/servlet/story/LAC.20170422.OBMARKWAINBERG/ BDAStory/BDA/deaths (consulté le 23 mai 2017). 